\title{
DISCHARGES OF TURBID WATER DURING MINI-SURGES OF VARIEGATED GLACIER, ALASKA, U.S.A.
}

\author{
By NeIl Humphrey, Charles Raymond, and Will Harrison
}

(Geophysics Program AK-50, University of Washington, Seattle, Washington 98195, U.S.A.)

\begin{abstract}
Discharges of water, sediment, and dissolved impurities from Variegated Glacier, Alaska, were monitored in the early summers of 1980 and 1981 during the occurrence of mini-surges. Seasonal trends, weather-related events, and diurnal variations similar to behavior of other temperate glacier streams were found. The principal effect in the stream associated with mini-surge occurrence was a brief discharge of extremely turbid water. The turbidity is assumed to be introduced into the basal hydraulic system by initiation of the fast motion of a mini-surge at a time and location on the upper glacier known from other measurements. The mean water velocity in the hydraulic system over the intervening distance is thereby determined $\left(0.3 \mathrm{~m} \mathrm{~s}^{-1}\right)$. The mean water velocity, together with the water discharge $\left(\approx 16 \mathrm{~m}^{3} \mathrm{~s}^{-1}\right.$ at the terminus), places constraints on the distribution of water velocity $u$ and total cross-sectional area $A_{\mathrm{T}}$ of the flow paths along the glacier base. This leads to the conclusion that within the zone of mini-surge occurrence in its unperturbed state: $u$ is about $0.1 \mathrm{~m} \mathrm{~s}^{-1}$ or possibly less; $A_{\mathrm{T}}$ is about $10^{2} \mathrm{~m}^{2}$ or possibly more, and it must be divided into a very large number of small passageways, be blocked by constrictions, or both. The total water cross-section corresponds to a layer $0.1-0.2 \mathrm{~m}$ thick when spread uniformly over the glacier width. The water velocity is close to or less than the propagation velocity of the mini-surges. Between the zone affected by mini-surges and the stream, a dynamically less active lower section of the glacier is probably underlain by a small number of conduits, in which the water velocity may be very high $\left(\geqslant 2 \mathrm{~m} \mathrm{~s}^{-1}\right)$. Water discharge following the minisurges puts an upper limit on water-storage changes associated with the anomalous ice motion.
\end{abstract}

RÉsumé. Écoulement d'eau chargée de sédiments au cours des mini-surges du Variegated Glacier, Alaska, U.S.A. L'écoulement de l'eau, des sédiments et des impuretés dissoutes venant du Variegated Glacier, Alaska, ont été suivis au début des étés 1980 et 1981 pendant les mini-surges. Des tendances saisonnières, des évènements fonction de la météorologie, et des variations semblables à celles des autres émissaires de glacier tempéré ont été rencontrés. La principale conséquence d'une mini-surge sur l'émissaire est constitué par un bref écoulement d'eau extrêmement trouble. On attribue l'origine de cette turbidité au système hydraulique qui à la base, lors du début du mouvement rapide d'une mini-surge, dès son développement dans la partie supérieure, connu par d'autres mesures. La vitesse moyenne de l'eau dans le système hydraulique sur la distance considérée est ainsi déterminée $\left(0,3 \mathrm{~m} \mathrm{~s}^{-1}\right)$. La vitesse moyenne de l'eau, avec le débit de l'émissaire $\left(\approx 16 \mathrm{~m}^{3} \mathrm{~s}^{-1}\right.$ au front), déterminent la répartition de la vitesse $u$ et de la surface transversale $A_{\mathrm{T}}$ des trajets d'écoulement le long du lit. Cela conduit à la conclusion que dans les zones où se produit la mini-surge on a pour l'état non perturbé: $u$ voisin de $0,1 \mathrm{~m} \mathrm{~s}^{-1}$ ou peut être moins; $A_{\mathrm{T}}$ voisin de $10^{2} \mathrm{~m}^{2}$ ou inférieur, qui peut être soit divisé en un très grand nombre de petits canaux, soit bloqués par fermeture, ou les deux à la fois. L'ensemble de l'eau dans une coupe transversale correspond à une couche de $0,1-0,2 \mathrm{~m}$ d'épaisseur pour un écoulement uniformément réparti sur la largeur du glacier. La vitesse de l'eau est voisine ou inférieure à la vitesse de propagation des minisurges. Entre la zone affectée par des mini-surges et le torrent sous glaciaire, une section inférieure dynamiquement moins active est probablement constitué par un petit nombre de conduits, dans lesquels la vitesse de l'eau peut être très élevée $\left(\geqslant 2 \mathrm{~m} \mathrm{~s}^{-1}\right)$. Le débit de l'eau qui accompagne les mini-surges définit une limite supérieure aux modifications du stockage de l'eau associé aux anomalies du mouvement de la glace.

ZUSAMMENFASSUNG. Abfluss trüben Wassers während Klein-Ausbrüchen des Variegated Glacier, Alaska, U.S.A. Abflüsse von Wasser, Sediment und gelösten Verunreinigungen aus dem Variegated Glacier, Alaska, wurden im Frühsommer der Jahre 1980 und 1981 während des Auftretens von Klein-Ausbrüchen festgestellt. Es zeigien sich jahreszeitliche Schwankungen, wetterbedingte Erscheinungen und tägliche Änderungen, ähnlich dem Verhalten anderer Ströme aus temperierten Gletschern. Der Haupteffekt im Abfluss bei Klein-Ausbrüchen war ein kurzer Austritt von extrem trübem Wasser. Es wird angenommen, dass die Trübung in das hydraulische System am Untergrund infolge des Beginns der schnellen Bewegung eines Klein-Ausbruchs an einer Stelle im oberen Gletscher eingeschleust wird, wie er aus anderen Messungen bekannt ist. Die mittlere Wassergeschwindigkeit im hydraulischen System über der dazwischenliegenden Strecke ist damit bestimmt $\left(0,3 \mathrm{~m} \mathrm{~s}^{-1}\right)$. Die mittlere Wassergeschwindigkeit liefert zusammen mit dem Abfluss $\left(\approx 16 \mathrm{~m}^{3} \mathrm{~s}^{-1}\right.$ an der Zunge) Aufschlüsse über die Verteilung der Wassergeschwindigkeit $u$ und den Gesamtquerschnitt $A_{\mathrm{T}}$ der Wasserführungen längs des Gletscherbettes. Dies führt zu dem Schluss, dass innerhalb der Zone des Eintritts von Klein-Ausbrüchen im ungestörten Zustand $u$ ungefähr $0,1 \mathrm{~m} \mathrm{~s}^{-1}$ oder weniger, $A_{\mathrm{T}}$ etwa $10^{2} \mathrm{~m}^{2}$ oder $\mathrm{mehr}$ ist, wobei eine Unterteilung in eine sehr grosse Zahl kleiner Durchlässe oder eine Blockade durch Verengungen oder beides vorliegen muss. Der gesamtte Wasserquerschnitt entspricht einer Schicht von $0,1-0,2 \mathrm{~m}$ Dicke, wenn man ihn gleichmässig über die Gletscherbreite verteilt. Die Wassergeschwindigkeit ist annähernd gleich oder geringer als die Fortpflanzungsgeschwindigkeit der Klein-Ausbrüche. Zwischen der von Klein-Ausbrüchen betroffenen Zone liegt unter einer dynamisch weniger aktiven unteren Partie des Gletschers vermutlich eine kleine Zahl von Führungen, in denen die Wassergeschwindigkeit sehr hoch sein kann $\left(\geqslant 2 \mathrm{~m} \mathrm{~s}^{-1}\right)$. Der Wasserabfluss im Anschluss an Klein-Ausbrüche setzt eine obere Grenze für die Änderungen des Wasserspeichers, die mit der ungewöhnlichen Eisbewegung verbunden sind. 


\section{INTRODUCTION}

The discharge of water, sediment, and dissolved materials from glaciers represents an important hydrological element in many mountain drainage basins. In a number of cases these discharges have been measured for down-stream use of the water for hydro-power production, irrigation, or water supply (Meier, 1969). These discharges also provide information about water storage in glaciers (Tangborn and others, 1975), erosion rates (Østrem, 1975), the chemical interaction of the waters with rock material in the basal zones, and properties of a glacier-drainage system (Collins, $1978,1979,1981$ )

Measurements of these discharges and their time variations are usually carried out as part of a hydrological program, which attempts to relate them to water input from ice melt and liquid precipitation and changes in water storage (Tangborn and others, 1975). It is also of interest to examine changes in these discharges in relation to changes in glacier speed (Paterson, 1964; Hodge, 1974), which can give information about the coupling between a glacier's hydrology and ice-motion dynamics.

This paper reports on variations of water discharge, suspended sediment concentration, and solute concentration observed during the "mini-surges" of Variegated Glacier, Alaska (Harrison and others, 1986; Raymond and Malone, 1986; Kamb and Engelhardt, in press). Mini-surge refers to an approximate doubling of speed for an interval of about $1 \mathrm{~d}$. These mini-surges occurred quasi-periodically in the early part of the melt seasons for at least the 4 years before the latest major surge of Variegated Glacier, which occurred in 1982 and 1983. Although the mini-surges on Variegated Glacier are apparently premonitory to the main surge, similar mini-surge behavior may occur on non-surgetype glaciers (Iken, 1978).

The measurements reported here were made in 1980 and 1981 on the principal stream draining the glacier. The water discharge, suspended sediment concentration, and solute concentration all showed trends and distinct fluctuations as the melt seasons progressed. The principal effect in the stream associated with mini-surges was a dramatic pulse in suspended sediment concentration far above variations from other sources. Broad low-amplitude waterdischarge peaks could also be distinguished but these were not clearly distinct from variations due to other causes. Changes in solute concentration occurring with mini-surges could not be resolved above the background variations.

These observations are interpreted to infer water velocity beneath the glacier, cross-sectional area of watertransmitting passageways, constraints on the geometry of the passageways, and the amount of water-storage change associated with mini-surges.

\section{DESCRIPTION OF VARIEGATED GLACIER}

Figure 1 shows a map of Variegated Glacier and the divide of its drainage basin. The glacier has a total length of $20 \mathrm{~km}$, an altitude range from $100 \mathrm{~m}$ to $2000 \mathrm{~m}$, and a typical equilibrium-line altitude of about $900 \mathrm{~m}$. Locations on the glacier are specified in kilometers from the head of the glacier.

During 1980 and 1981 three streams drained the glacier (Fig. 1). The largest of these streams, here referred to as the upper stream, exited the glacier at about $\mathrm{km} 16 \frac{1}{2}$ on the south margin of the terminal lobe and carried roughly $65 \%$ of the total discharge. Above this location the area of Variegated Glacier is $21 \mathrm{~km}^{2}$, the area of other glacier ice is about $24 \mathrm{~km}^{2}$, and the total drainage basin area is $72 \mathrm{~km}^{2}$. The second largest stream, here referred to as the lower stream, exited the glacier at about $\mathrm{km} 20$ on the west margin of the terminal lobe and carried roughly $30 \%$ of the total discharge. Between $\mathrm{km} 16 \frac{1}{2}$ and the lower stream, there is $6 \mathrm{~km}^{2}$ of Variegated Glacier and no significant other drainage area. The third stream carried less than $5 \%$ of the total discharge.

The geometry and motion of Variegated Glacier have been described by Bindschadler and others (1977). A seasonal and shorter-period variation of sliding velocity and near-surface temperature measurements indicate a temperate thermal regime, which is consistent with its low altitude in a maritime environment (Bindschadler and others, 1976). Water-equivalent annual net balance ranges from $-5 \mathrm{~m}$ to $+4 \mathrm{~m}$. The geometry, corresponding stress distribution, and speed have been changing since initiation of measurements in 1973 (paper in preparation by C.F. Raymond and W.D. Harrison).

In the zone $3-9 \mathrm{~km}$ from the glacier head, thickness, slope, basal shear stress, and speed had all progressively increased up to September 1981. By 1981, these parameters had values for this zone about $300-400 \mathrm{~m}$ for ice depth, $5-6^{\circ}$ for slope, 1.4-1.8 bar for basal shear stress, and $0.4-1.1 \mathrm{~m} \mathrm{~d}^{-1}$ for summer-averaged speed. During the minisurges, peak velocities exceeded $3 \mathrm{~m} \mathrm{~d}^{-1}$ and, averaged over a day, reached levels of $2 \mathrm{~m} \mathrm{~d}^{-1}$ (Harrison and others, 1986; $\mathrm{Kamb}$ and Engelhardt, in press). These mini-surges lasted about $1 \mathrm{~d}$ and recurred about once per week in June and July. Individual mini-surges showed a space-time evolution usually characterized by initiation of rapid motion in a localized zone of a few kilometers length with subsequent down-glacier propagation at speeds of $0.1-0.6 \mathrm{~km} \mathrm{~h}^{-1}$.

Over the glacier below about $\mathrm{km} \mathrm{11}$, thickness had decreased progressively, slope increased progressively, and basal shear stress and velocity remained roughly constant up to September 1981. Seasonal variation of velocity was also apparent in this zone with summer-averaged speed reaching up to $0.3 \mathrm{~m} \mathrm{~d}^{-1}$ in the upper reaches, but no high-speed velocity anomalies occurred (Harrison and others, 1986).

\section{STREAM MEASUREMENTS}

Table I lists the principal types of measurements, when they were made, and the sampling frequency. In 1980, measurements were made with manually operated instruments. These were automated in 1981.

\section{LEGEND}

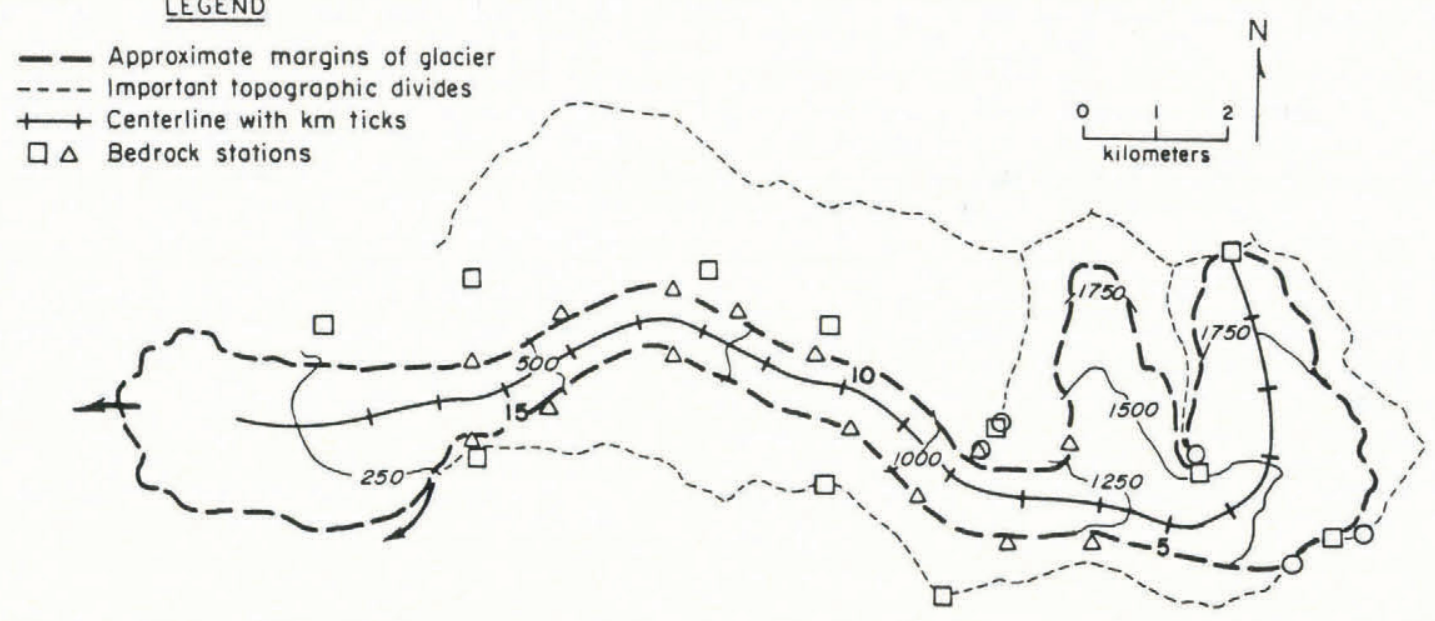

Fig. 1. Map of Variegated Glacier showing discharge-stream locations. 
TABLE I. MEASUREMENT HISTORY

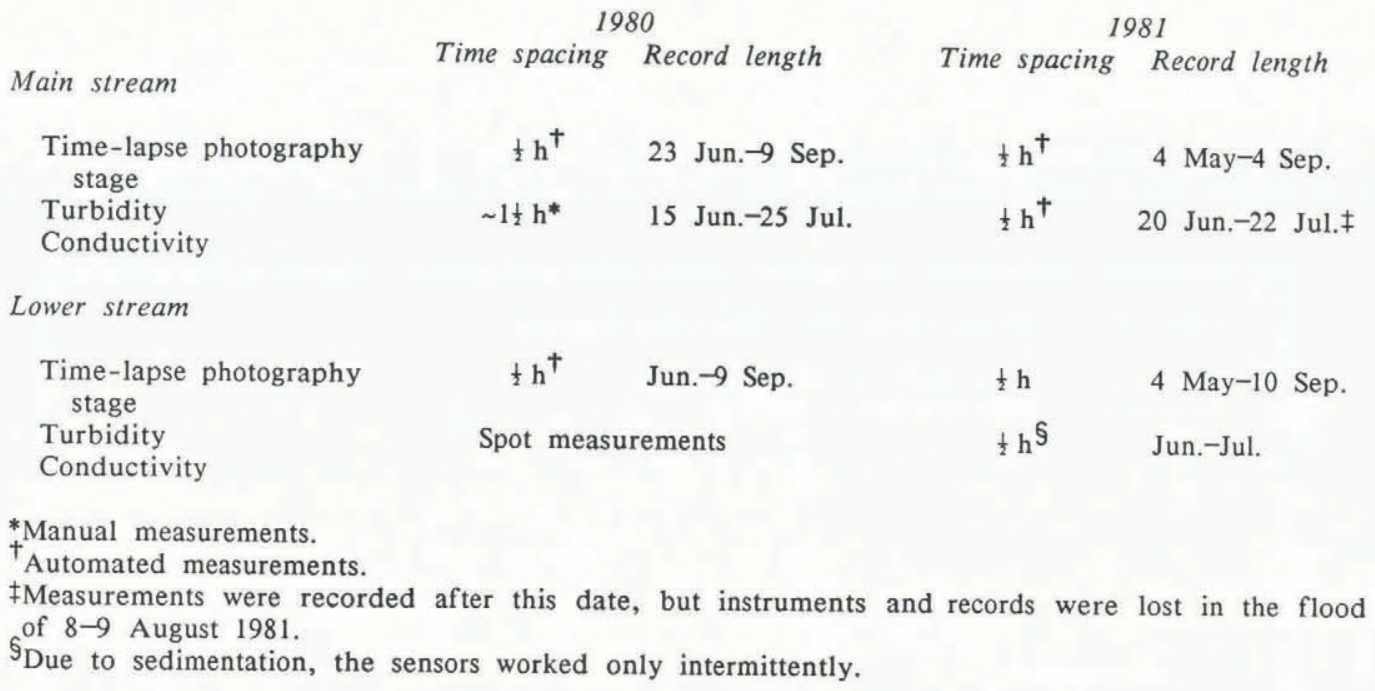

Time-lapse photography was used to record shifts in the stream channel, to time major changes in discharge, and to give a semi-quantitative record of stream stage. For this purpose, super-8 cine cameras were used in single-frame mode with triggering from a programmable external crystal clock.

Precise data on stage were obtained at the main stream by manual measurement against a fixed staff in the summer of 1980 and recording of level in a stilling well in 1981 . These were positioned in the one cross-section bounded by bedrock. Both manual and automated measurements gave local stage accurate to about $0.01 \mathrm{~m}$, but dynamic effects caused by the fast water and rough bed resulted in differences between local and area-averaged surface level up to $0.1 \mathrm{~m}$.

The main stream was gauged 12 times in 1980. These water-discharge measurements were plotted with the stage to construct a stage-rating curve. The relationship between mean water velocity $u$, hydraulic radius $R$, and stream gradient $J$ corresponded to Manning's equation

$$
u=\frac{R^{2 / 3} J^{1 / 2}}{n}
$$

with roughness $n$ of 0.034 . Calculation of the discharge from the stage was complicated by changes in the stream bed and banks due to erosion and deposition, which could only be partly corrected by resetting of the stage reference level. The net bed erosion at the bedrock gap was about $0.2 \mathrm{~m} \mathrm{a}^{-1}$ for 1980 and 1981 .

Water turbidity was measured as an indirect indicator of suspended sediment concentration (hereafter referred to as sediment concentration). This was done using a specially constructed meter, which compared the light transmitted from a controled incandescent lamp to two photo resistors. One light path was unobstructed, and the second was through a layer of stream water (usually about $5 \mathrm{~mm}$ thick).

An approximate relationship between turbidity reading and sediment concentration was established in 1983 by comparison of a series of 200 coincident stream-turbidity measurements and water-sample collections giving direct measurement of suspended load. This relationship fits the form

$$
\left.S=\exp \left[a^{*} R-b\right)\right]
$$

where $S$ is the suspended load, $R$ is turbidity-meter reading, and $a$ and $b$ are fitting parameters. The form of this equation is affected strongly by the characteristics of the electronics and photo cells. Equation (2) gives an accuracy of about $15 \%$. The scatter between the sample sediment concentration and turbidity arises presumably from particle-size distribution or composition. Also, the water samples collected in the bottles and the water viewed in the turbidity meter were not identical due to some difference in time and position, and substantial local structure to the sediment concentration from turbulence. The turbidity-meter reading of ten showed $\sim 5 \%$ fluctuations at frequencies up to $1 \mathrm{~Hz}$ during measurement which the operator had to visually average.

The relationship in Equation (2) was also used in 1980 and 1981 for the conversion of turbidity reading to sediment concentration. Because instruments with different photo cells and water gaps were used, the parameters $a$ and $b$ had to be refitted for various segments of the data records usually with only a few samples for calibration. Consequently, the error could be worse than the $15 \%$ range found in 1983 .

Electrical conductivity of stream water was measured with standard commercial platinum-electrode conductivity cells with specified cell constants of $0.1 \mathrm{~cm}$ (plate area/plate spacing) read using a $1 \mathrm{kHz}$ square-wave conductivity
bridge.

Water temperature was measured periodically and was always $0.2^{\circ} \pm 0.1^{\circ} \mathrm{C}$. This variation in temperature has negligible effect on conductivity, and all conductivity changes represent changes in water chemistry. Although suspended load variations represent a variable proportion of water and rock cross-section to electric current flow, the major effect is the concentration of ions in the water.

The relationship between conductivity and specific ion content has not been investigated thoroughly. If the proportion of ion types does not change, the ion concentration would be proportional to specific conductance because of the low concentration and expected ideality of the solution. Plasma-spectroscopic measurement of two samples showed the major anion to be calcium $(\approx 90 \%)$ with small amounts of potassium $(\approx 5 \%)$, silicon, sodium, magnesium, iron, and aluminum. Based on these atomic proportions, an approximate conversion between total dissolved solids (TDS), hereafter referred to as solute concentration, and specific conductance $K$ (cell resistance $\times$ cell constant $)^{-1}$ of the solution is:

$$
\operatorname{TDS}(\mathrm{g} / \mathrm{l})=(1.0) K
$$

This is consistent with a standard conversion for ground water (Greenberg and others, 1981) when the $0^{\circ} \mathrm{C}$ temperature of the stream water is taken into account. 


\section{BACKGROUND BEHAVIOR OF THE STREAMS}

The two major drainage outlets from the glacier behaved differently. In comparison with the lower stream, the upper stream showed discharge higher by a factor of 2 (Fig. 2), solute concentration higher by a factor of 2 , and sediment concentration higher by a factor of 4 . In contrast, diurnal variations of discharge and solute concentration were proportionally much larger on the lower stream than the upper stream. Variations of sediment concentrations were small in the lower stream. These comparisons indicate that the primary water source for the lower stream was ice melt on the lower lobe close to the outlet. Therefore, the upper stream carried most of the drainage from the main body of the glacier including the accumulation zone, and the area of mini-surge activity.

Figure 2 shows the seasonal variation of daily maximum and minimum discharge in the upper stream estimated from time-lapse photography for 1980 and 1981 . During late spring and early summer, there was a gradual, fairly smooth rise in discharge, followed by a more rapid rise during a short 1 or 2 week period. The summer period
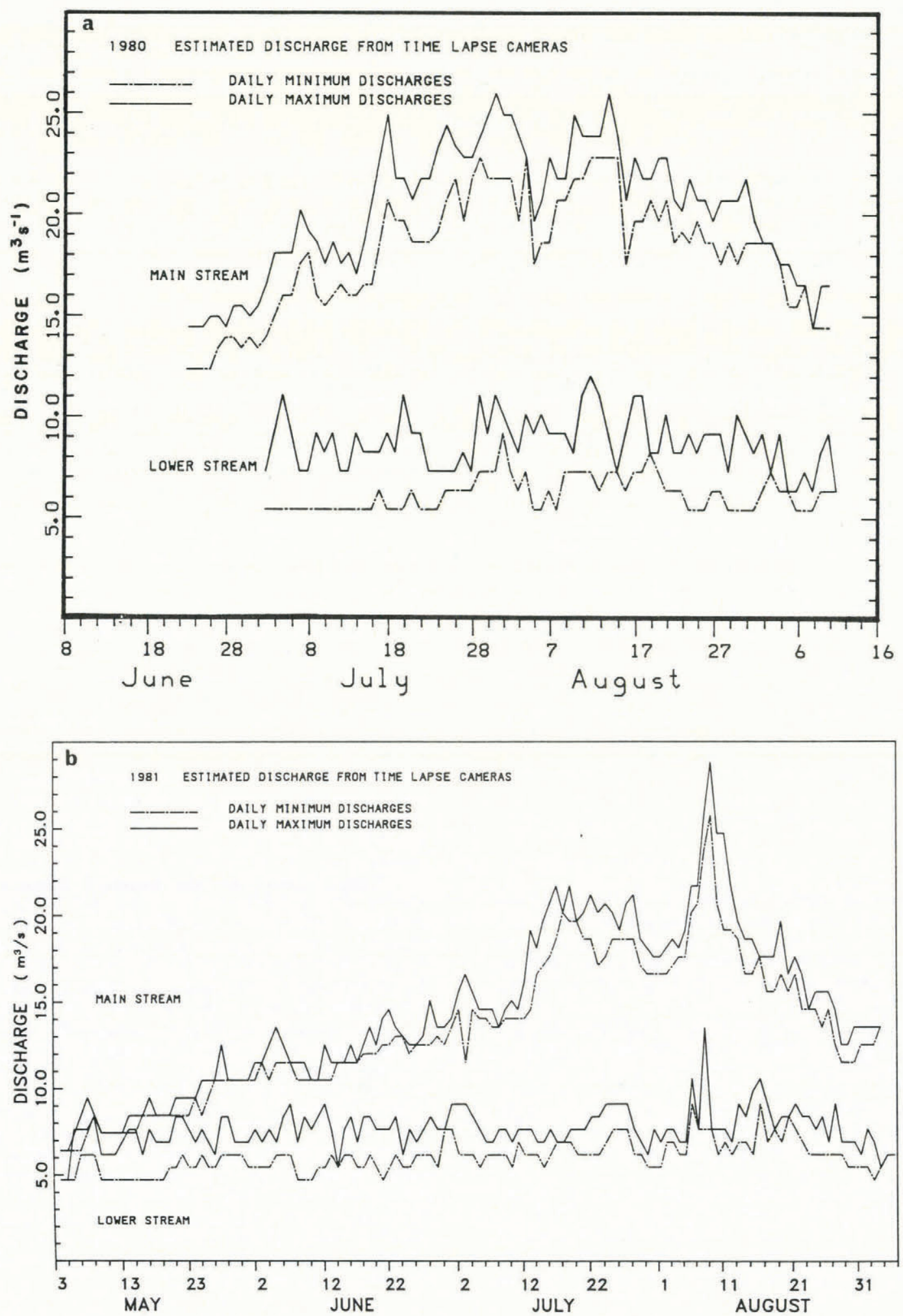

Fig. 2. a. Maximum and minimum discharge of the upper stream estimated each day from time-lapse photography. b. Maximum and minimum discharge of the lower stream estimated each day from time-lapse photography. 

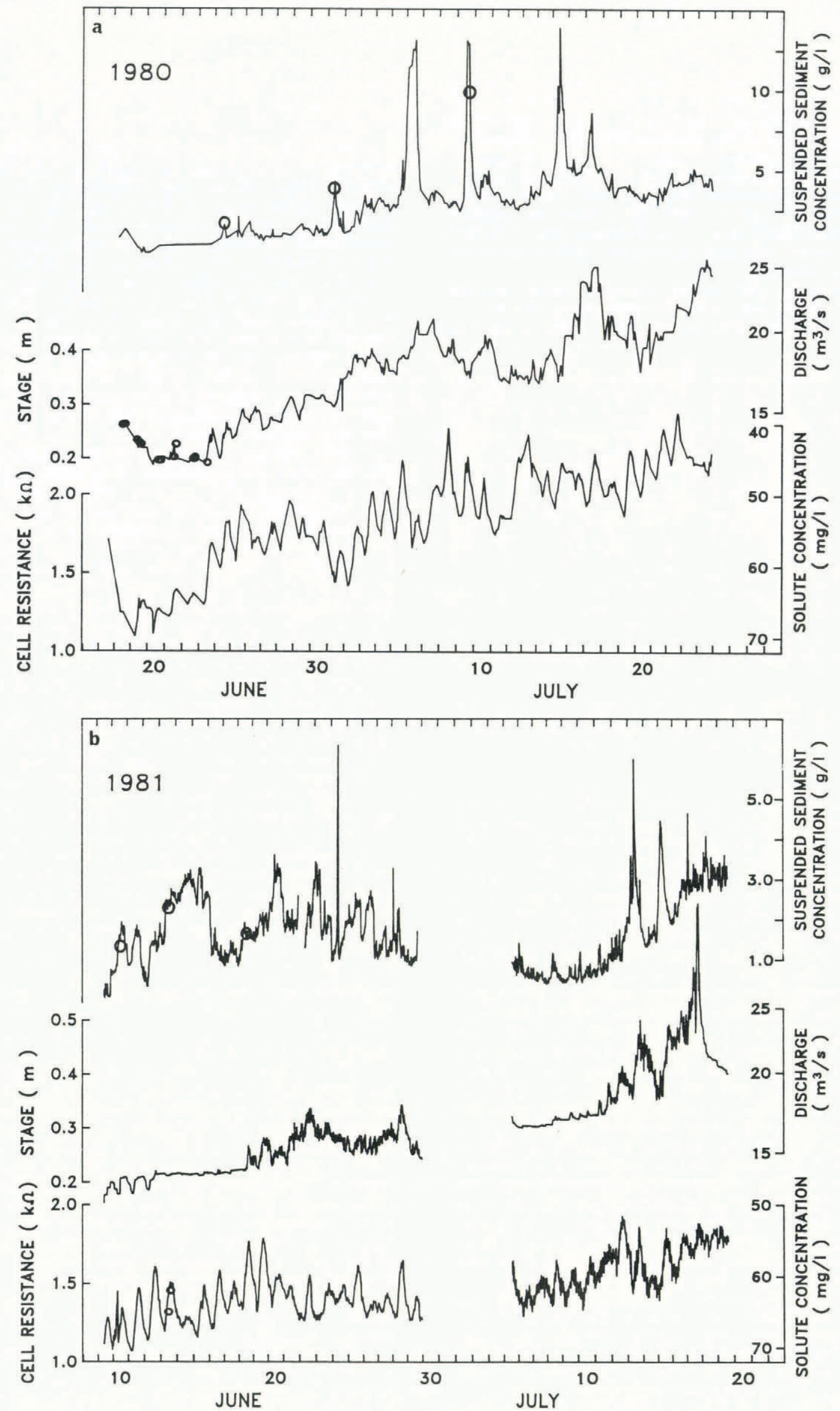

Fig. 3. Measurements of water resistivity, turbidity, and stage of main stream for measurement intervals of (a) 1980 and (b) 1981. Measurement spacing is about $11 \mathrm{~h}$ in 1980 and $30 \mathrm{~min}$ in 1981. Approximate conversions to total dissolved solid concentration; suspended sediment load and water discharge are explained in the text. Points show direct measurements of discharge and suspended sediment concentration used to calibrate stage and turbidity. 
was characterized by large discharge fluctuations controled by major storms. In 1981, the decline of the discharge back to winter levels was more rapid than the spring rise.

Figure $3 \mathrm{a}$ and $\mathrm{b}$ shows the more detailed records of stage, turbidity, and specific conductance from late spring and early summer. The specific conductance shows a trend opposite to the discharge, implying an inverse relationship between discharge and solute concentration. For convenience, resistivity is plotted instead of conductivity and the corresponding solute concentration increases downward in Figure 3. The solute concentration early in the season before discharge increase is up to $50 \%$ more than the summer average of about $50-60 \mathrm{mg} \mathrm{l}^{-1}$. The turbidity was very low in the early season and high in summer, and is positively correlated with discharge.

Figure 4 shows the summer-averaged diurnal records for stage, resistivity, and turbidity. Each curve was calculated by averaging all observations made over a summer
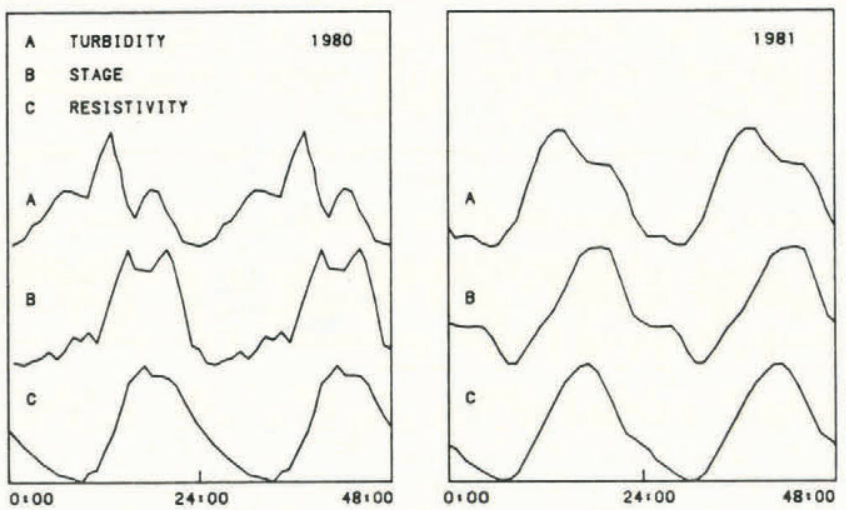

Fig. 4. Stacked daily records of turbidity, stage, and resistivity. Each curve is scaled to approximate the same amplitude for comparison of shape and phase.

during a particular hour and then smoothing with a $3 \mathrm{~h}$ averaging filter. Days of mini-surges and major storms were omitted in the stacking of the turbidity and stage data. The three curves were normalized to the same amplitude for easy comparison of shape and phase. For 1980, the records were poorly defined from 22.00 to $06.00 \mathrm{~h}$ because of a lower night-time sampling rate. The data for 1981 were obtained on a continuous half-hour cycle; the variance of the data for any one hour from their mean was fairly independent of time of day.

In comparison to their ranges over the full record length, excluding storms and mini-surges, the full amplitude of the diurnal variation was about $25 \%$ for resistivity, $20 \%$ for discharge, and about $10 \%$ for turbidity. In comparison to their averages over the record length, the diurnal variation was about $10 \%$ for resistivity and $6 \%$ for discharge. The magnitude of the diurnal variation depended on the weather, with the largest variations found on sunny days. The amplitude of the daily cycle tended to increase with time during the early part of summer. The discharge peak occurred in the afternoon $(17.00-19.00 \mathrm{~h})$ and the correlation of amplitude with weather showed that the peak represented melt-water input on the same day. The diurna stage and resistivity variations were closely in phase. Even though the turbidity signal was weak, it showed a definite phase difference with the daily discharge peak.

Combination of the solute concentration with water discharge gives the solute load (flux). In the typical diurnal cycle the solute load was roughly constant at about $0.9 \mathrm{~kg} \mathrm{~s}^{-1}$. (Actually there appears to be a slight decrease in solute load with increasing water flux, with a diurnal amplitude that was about $\pm 2 \%$ of the above.)

The suspended sediment load calculated from sediment concentration and water flux was typically about $50-75 \mathrm{~kg} \mathrm{~s}^{-1}$ with a diurnal amplitude of $\pm 5 \%$ of the above.

Local effects at the stream portal and between the portal and the measurement sites approximately $100 \mathrm{~m}$ down-stream affected measurements. The most relevant was an occasional peak in turbidity lasting $2 \mathrm{~h}$ or less caused by ice fall into the stream portal and partial damming of the stream.

\section{ANOMALOUS BEHAVIOR IN UPPER STREAM FROM MINI-SURGES}

Seven mini-surges occurred during the time of stream observations, four in 1980 and three in 1981 (Raymond and Malone, 1986; Kamb and Engelhardt, in press). The principal effect seen in the stream at the time of a mini-surge was a dramatic peak in the sediment concentration (turbidity pulse) lasting a number of hours (Fig. 3a and b). The timings of the turbidity pulses in relation to the mini-surge initiations on the upper glacie are given in Table II. One mini-surge produced no discernible turbidity pulse (24 June 1981). The turbidity pulses typically had a peak of 2 or $3 \mathrm{~h}$ during which the water was so opaque that the turbidity meter was saturated. The peak occurred within $4-10 \mathrm{~h}$ of the onset. Samples indicated peak sediment concentrations of over $10 \mathrm{~g} / 1$. The pulses lasted for $24 \mathrm{~h}$ or more with a slow decline from the peak to a background level.

There was not an obvious discharge anomaly; however, five mini-surges were followed after 1 or $2 \mathrm{~d}$ by a broad rise in discharge of 1 or $2 \mathrm{~d}$ duration (Fig. $3 \mathrm{a}$ and b). Since the amplitude of the rises was of the same order as the observed background variability, it is not unequivocal that these were caused by the mini-surges. Figure 5 shows the record of discharge from 1980 mini-surges superposed so that the times of the corresponding turbidity peaks coincide. The typical diurnal variations (Fig. 4) were subtracted The two 1981 mini-surges for which turbidity pulses were recorded occurred close together (Table II) and at a time of complex discharge variations (Fig. 3b), so these were not included in the data stacking. The combined data show a rise in discharge starting at the time of the turbidity peak which continued to reach a maximum of about $1 \frac{1}{2} \mathrm{~m}^{3} \mathrm{~s}^{-1}$ above background 1-2 d later. A displacement in background before and after the mini-surge exists because the minisurges occur in a time of rising discharge trend (Fig. 3a). The total extra discharge associated with mini-surge occurrence implied by Figure 5 is about $3 \times 10^{5} \mathrm{~m}^{3}$

There was no discernible anomaly in solute concentration associated with the mini-surges. This implies a dissolved load anomaly proportional to the water-discharge anomaly. This behavior in response to the mini-surges is opposite to the diurnal variation where solute concentration varies inversely with discharge and solute load is nearly constant.

\section{FRAMEWQRK FOR INTERPRETATION OF TURBIDITY RISE}

\section{Origin of turbidity pulse}

Since there was no exceptional discharge increase associated with the mini-surge turbidity pulses, the high turbidity is not generated locally near the stream portal by fluvial activation of sediments in water passageways nor does it represent the release of a reservoir of stored turbid water. A reasonable assumption is that the high turbidity is caused by entrainment of sediment into the basal hydraulic system in the zone affected by the mini-surge motions. The actual mechanisms of turbidity generation are unknown possibilities are direct mechanical action of the rapidly sliding ice, or exposure of new areas of the bed to turbulent water flow. Once sediment is entrained in the water flow it serves as a tracer as long as its settling velocity $\left(\sim 10^{-2} \mathrm{~m} \mathrm{~h}^{-1}\right)$ is opposed by sufficient turbulence to maintain suspension.

In the initial discussion it is assumed (i) that sediment is first injected at the time and location of mini-surge initiation, (ii) that the water-flow regime below this point is turbulent, and (iii) that the water-flow velocity is greater than or equal to the rate of down-glacier propagation of the ice-motion disturbance of the mini-surge $\left(0.1-0.6 \mathrm{~km} \mathrm{~h}^{-1}\right)$. With these assumptions, the leading edge of the turbidity cloud would measure the average water velocity in the unperturbed basal hydraulic system between 


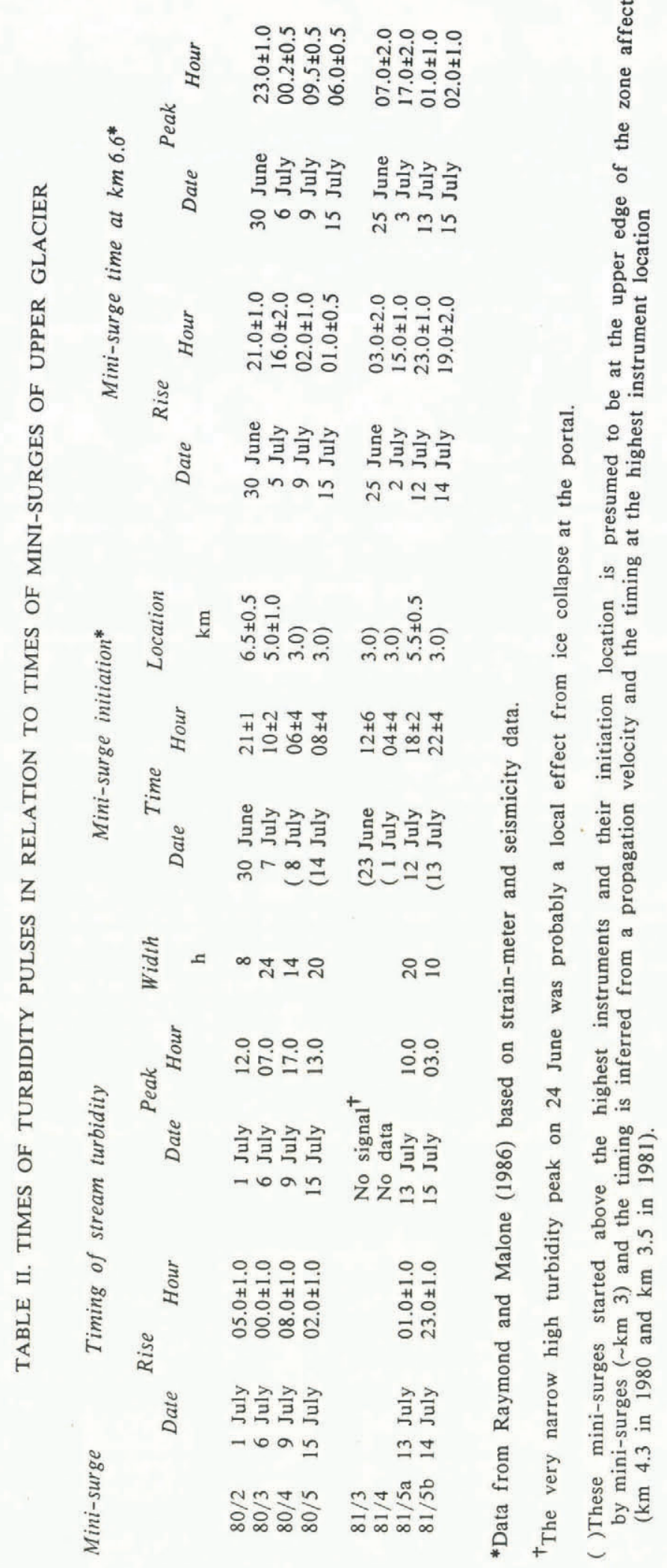




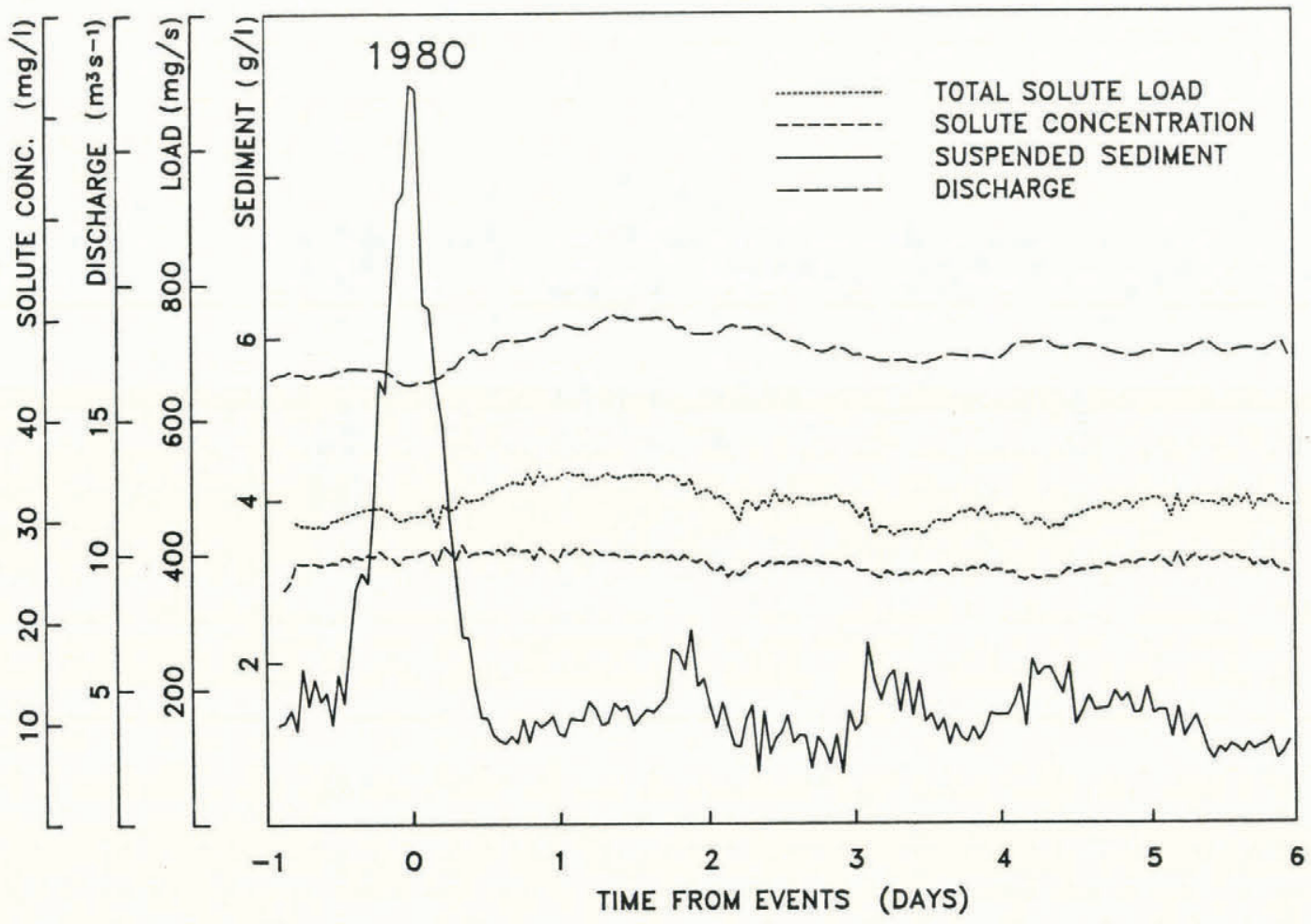

Fig. 5. Stacked records of discharges and concentrations from the four mini-surges of 1980 with diurnal signal removed. Time origins for each mini-surge were taken as the time of peak turbidity.

the mini-surge initiation location and the stream portal. The resulting average water velocities are tabulated in Table III and are not inconsistent with these assumptions. However, as our discussion expands we will have to re-assess the validity of the above assumptions.

\section{Longitudinal distribution of water flux}

If at a given longitudinal position $x$ water is collected from a width $W(x)$ and the width-averaged water input per unit area is $b(x)$, then the water flux $Q$ is given by

$$
Q(x)=\int_{0}^{x} b\left(x^{\prime}\right) W\left(x^{\prime}\right) \mathrm{d} x^{\prime}
$$

assuming steady-state water storage. We define

$$
S(x)=\int_{0}^{x} W\left(x^{\prime}\right) \mathrm{d} x^{\prime},
$$

so that $S(x)$ is the total collection area above position $x$. This is plotted in Figure 6 assuming $W(x)$ is the width of the glacier. The discontinuity between $\mathrm{km} 5$ and 6 represents the contribution to $S$ from the major tributary.

Based on the typical upper-stream discharge of about $16 \mathrm{~m}^{3} \mathrm{~s}^{-1}\left(14 \times 10^{5} \mathrm{~m}^{3} \mathrm{~d}^{-1}\right)$, the average value of $b(x)$ between the head $(x=0)$ and the stream portal would be $0.067 \mathrm{~m} \mathrm{~d}^{-1}$.

TABLE III. MEAN VELOCITY OF LEADING EDGE OF TURBIDITY RISE

a. Over full length

Distance $^{*} \Delta t^{*} \quad\langle u\rangle \quad$ Distance $^{\dagger} \Delta t^{\dagger}$

$\begin{array}{lccccc} & \mathrm{km} & \mathrm{h} & \mathrm{km} \mathrm{h}^{-1} & \mathrm{~km} & \mathrm{~h} \\ 80 / 2 & 10.0 \pm 0.5 & 8.5 \pm 1 & 1.2 \pm 0.2 & 2.5 & 6.5 \\ 80 / 3 & 11.0 \pm 0.5 & 13 \pm 2 & 0.8 \pm 0.1 & 3.5 & 11 \\ 80 / 4 & 13.5 \pm 0.5 & 29 \pm 4 & 0.5 \pm 0.1 & 6.0 & 27 \\ 80 / 5 & 13.5 \pm 0.5 & 22 \pm 4 & 0.6 \pm 0.2 & 6.0 & 20 \\ & & & & & \\ 81 / 5 \mathrm{a} & 11.0 \pm 0.5 & 9.5 \pm 2 & 1.2 \pm 0.5 & 3.5 & 7.5 \\ 81 / 5 \mathrm{~b} & 13.5 \pm 0.5 & 26 \pm 4 & 0.5 \pm 0.1 & 6.0 & 24\end{array}$

*To stream portal

${ }^{\dagger}$ To $\mathrm{km} 9$ assuming $2 \mathrm{~h}$ transit time from $\mathrm{km} 9$ to stream portal.

‡From Raymond and Malone (1986, table II).

( ) These error estimates do not allow for possible error in transit time from $\mathrm{km} 9$ to stream portal which is assumed to be $2 \mathrm{~h}$. 


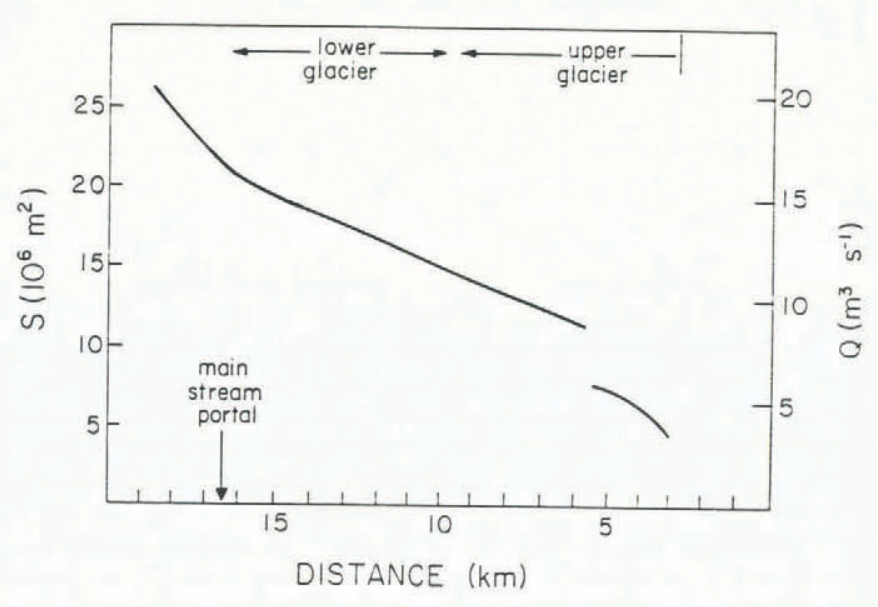

Fig. 6. Glacier width integrated from the glacier head and steady-state water discharge, assuming water input averaged over the width is independent of longitudinal position. Arrows show location of main stream $(\mathrm{km} \mathrm{16t)}$ and boundary between upper and lower glacier regimes ( $\mathrm{km} \mathrm{9t)}$. Head of glacier is on the right.

This is roughly consistent with the input expected from ice ablation, and the steady state assumed above, but neither the melt input nor the discharge output are known accurately enough to assess any trend in water storage from this comparison. The ablation rate usually decreases upglacier and ablation rate is lower over snow, which would tend to make $b(x)$ decrease up-glacier. On the other hand, there is more ice and snow on the valley walls outside the glacier margins in the upper part of the basin and this water input from the sides would tend to make $b(x)$ increase up-glacier when it is figured relative to the width of the glacier as above. These two effects may partly cancel and it is not unreasonable to assume $b(x)=b$ a constant. Thus

$$
Q(x)=b S(x) .
$$

Figure 6 shows $Q(x)$ assuming $b=0.067 \mathrm{~m} \mathrm{~d}^{-1}$.

\section{Cross-sections of water-flow passageways}

Based on continuity, the total cross-section area $A_{\mathrm{T}}$ carrying water flux $Q$ at mean water velocity $u$ is

$$
A_{\mathrm{T}}=Q / u \text {. }
$$

Thus, if the distribution of $u$ along the length of the glacier were known, then in combination with $Q$ from Figure 6 the distribution of $A_{\mathrm{T}}$ could be determined.

Based on fluid dynamics, the water velocity is expected to be related to the geometry of the passageways and the hydraulic gradient. The geometry of the passageways could have a number of conceivable forms. As a reference example geometry, we choose a tube-like conduit in the ice, such as analysed by Röthlisberger (1972). If the water flows turbulently in a conduit of hydraulic radius $R^{\prime}$, cross-section area $A_{\mathrm{c}}^{\prime}$, Manning roughness $n^{\prime}$, and hydraulic gradient $J^{\prime}$, its velocity $u^{\prime}$ may be found from Manning's Equation (1), now expressed as

$$
u^{\prime}=R^{\prime 2 / 3} \frac{J^{\prime 1 / 2}}{n^{\prime}}=\left(\frac{s A_{C}^{\prime}}{4 \pi}\right)^{1 / 3} \frac{J^{\prime}{ }^{1 / 2}}{n^{\prime}} .
$$

( $s=4 \pi R^{2} / A_{\mathrm{c}}^{\prime}$ is a shape factor which would have a maximum value of 1 for a circular cross-section.) If the conduit is straight and runs parallel to the down-glacier direction, then $u^{\prime}, A_{\mathrm{c}}^{\prime}$, and $J^{\prime}$ are straightforwardly interpreted as the down-glacier water velocity, the conduit flow cross-section perpendicular to the down-glacier direction, and the down-valley hydraulic gradient. If the conduit is sinuous and does not everywhere run parallel to down-glacier, this equation can be modified. The sinuosity $\gamma$ may be defined as the length of conduit per unit down-valley length. ( $\gamma$ has a minimum value of 1.) The down-glacier water velocity $u$, the conduit area normal to the down-glacier direction $A_{\mathrm{c}}$, and the mean hydraulic gradient down the valley $J$ are related to $u^{\prime}, A_{\mathrm{c}}^{\prime}$, and $J^{\prime}$ by $u=u^{\prime} / \gamma$, $A_{\mathrm{c}}=A_{\mathrm{c}}^{\prime} \gamma, J=J^{\prime} \gamma$ when averaged over length. If it is assumed that $J^{\prime}$ is constant along the conduit axis, then substitution into Equation (8a) gives

$$
u=\left[\frac{A_{\mathrm{C}}}{4 \pi}\right]^{1 / 3} \frac{J^{1 / 2}}{n}
$$

where $n=n^{\prime} \gamma^{11 / 6} / s^{1 / 3}$ is an effective roughness. The effective roughness $n$ is larger than the roughness $n^{\prime}$ as a result of sinousity $(\gamma \geqslant 1)$ or deviation from circular cross-section $(s \leqslant 1)$. This effective roughness has been found empirically to be about $0.1 \mathrm{~m}^{-1 / 3} \mathrm{~s}$ (Röthlisberger, 1972; Nye, 1976; Clarke, 1982) and its large size in comparison to typical roughnesses of tubes $\left(0.06 \mathrm{~m}^{-1 / 3} \mathrm{~s}\right)$ may arise from a small sinuosity $(\gamma=1.5)$. The hydraulic gradient $J$ can be estimated over most of the glacier length by the average slope of the ice surface (Röthlisberger, 1972), which is about 0.1 on Variegated Glacier. by

The Reynolds number for the conduit flow is given

$$
\operatorname{Re}=\frac{\rho u D_{c}}{\eta}
$$

where $\rho$ and $\eta$ are the density and viscosity of water, and $D_{c}$ is an effective diameter. In order for Equations (8) to be valid, the flow must be turbulent which occurs for $\operatorname{Re}>2100$ (Baer, 1972).

Below we shall be concerned with a comparison of results from Equations (7) and (8) to see if the basal hydraulic system could be composed of tube-like conduits and otherwise to place constraints on the structure of the flow passageways.

\section{STRUCTURE OF THE BASAL HYDRAULIC SYSTEM}

\section{Evidence for a distributed flow system}

Suppose water velocity were constant along the length of the glacier and equal to the average of about $0.3 \mathrm{~m} \mathrm{~s}^{-1}$ $\left(1 \mathrm{~km} \mathrm{~h}^{-1}\right)$ from Table IIIa. Then from Equation (7) $A_{\mathrm{T}}$ would be proportional to $Q$ and the distribution of $A_{\mathrm{T}}$ along the glacier would be pictured by Figure 6 with the appropriate scaling of the $Q$-axis. For example, $A_{\mathrm{T}} \approx 27 \mathrm{~m}^{2}$ at $\mathrm{km} 6$ and $A_{\mathrm{T}} \approx 54 \mathrm{~m}^{2}$ at $\mathrm{km} \mathrm{16}$. Based on Equation (8b), the above water velocity would be achieved in a conduit of cross-section area $A_{\mathrm{c}}=0.9 \times 10^{-2} \mathrm{~m}^{2}$ (diameter $D_{\mathrm{c}}=$ $0.10 \mathrm{~m})$. The corresponding Reynolds number would be $14 \times 10^{3}$.

The total flow cross-section $A_{\mathrm{T}}$ needed to carry the flux at the assumed velocity is $10^{3}-10^{4}$ larger than the cross-section $A_{\mathrm{c}}$ of a conduit of size compatible with that velocity. This comparison shows that the actual geometry of $A_{\mathrm{T}}$ must be much more complex than a typical Röthlisberger conduit.

In actuality, water velocity may vary along the length of the glacier. Where the velocity is much faster than average, the flow might be concentrated into one or a few large conduits. But it seems certain over some length of the glacier the water flow must be through a distributed flow geometry.

\section{Two-zone model of flow system}

There are a number of lines of evidence for doubting that water flow along the bed is everywhere through a distributed flow system. One would be the purely theoretical argument presented by Shreve (1972) and Röthlisberger (1972) which shows that large conduits would tend to capture the flow of small ones. A configuration of many small passageways would tend to be unstable at least if the conduits are Röthlisberger channels in the basal ice. The stream exits the glacier from a tunnel which must extend back up the glacier some distance. Over much of the 
glacier below $\mathrm{km} 10$ much melt water enters the glacier in moulins which probably persist as concentrated flow paths at depth. The very strong diurnal variation of solute concentration indicates a transit time from large areas of the glacier to the stream that is short compared to a day, which is discussed in more detail later. Also, the turbidity peak in the stream is not much broader than the interval of mini-surge activity (Table II) and therefore it is transported beneath the lower glacier with little dispersion. Finally, such a layer would seem inconsistent with the dynamic behavior of the glacier, if the layer extended over the full length. Above $\mathrm{km} \mathrm{9,} \mathrm{the} \mathrm{glacier} \mathrm{experienced} \mathrm{rapid} \mathrm{summer} \mathrm{sliding}$ (up to $0.9 \mathrm{~m} \mathrm{~d}^{-1}$ for full summer average) and mini-surges; but below about $\mathrm{km} 10$ the summer sliding was small $\left(0.2 \mathrm{~m} \mathrm{~d}^{-1}\right.$ or less) and there were no large mini-surge-like motions (Harrison and others, 1986).

For these reasons, we consider an alternative model described by a conduit which extends from the stream portal at $\mathrm{km} \mathrm{16 \frac {1 } { 2 }}$ up-glacier to about $\mathrm{km} \mathrm{10}$, a more distributed layer-like system above $\mathrm{km} \mathrm{9}$, and a short transition zone in between. This boundary between conduit and layer-like flow is positioned on the upper limit of moulins and the lower limit of the mini-surges, described above. This boundary also happens to coincide with the upper edge of a short section of the glacier which is steeper and more highly crevassed than any other section of the main glacier below $\mathrm{km} 3$ and which may have some mechanical importance in dividing the upper and lower parts of the glacier.

To analyze this two-zone flow system, we first calculate the circular conduit size needed to carry the water flux in the lower zone below $\mathrm{km} \mathrm{10}$. From Equation (8b)

$$
Q=u A=\left(1.2 \times 10^{4} \mathrm{~m}^{1 / 3} \mathrm{~d}^{-1}\right)^{-\frac{A}{\mathrm{c}^{4 / 3}}} \frac{}{n}
$$

With $n=0.1 \mathrm{~m}^{-1 / 3} \mathrm{~s}$, this predicts $A_{\mathrm{c}}=6.4 \mathrm{~m}^{2} \quad\left(D_{\mathrm{c}}=2.9 \mathrm{~m}\right)$ for a flux of $16 \mathrm{~m}^{3} \mathrm{~s}^{-1}\left(1.4 \times 10^{6} \mathrm{~m}^{3} \mathrm{~d}^{-1}\right)$ at $\mathrm{km} \mathrm{16 \frac {1 } { 2 }}$, and $A_{\mathrm{c}}=5.0 \mathrm{~m}^{2} \quad\left(D_{\mathrm{c}}=2.5 \mathrm{~m}\right)$ for a flux of $9 \mathrm{~m}^{3} \mathrm{~s}^{-1}$ $\left(1.0 \times 10^{6} \mathrm{~m}^{3} \mathrm{~d}^{-1}\right)$ inferred for $\mathrm{km} \mathrm{10}$. The corresponding velocities $u$ are $2.5 \mathrm{~m} \mathrm{~s}^{-1}\left(9.1 \mathrm{~km} \mathrm{~h}^{-1}\right)$ and $2.3 \mathrm{~m} \mathrm{~s}^{-1}$ $\left(8.3 \mathrm{~km} \mathrm{~h}^{-1}\right)$. In all of these circumstances the corresponding Reynolds numbers would be high $\left(\operatorname{Re}>10^{6}\right.$ ) and the flow is certainly turbulent. The above-inferred velocities are similar to the water velocity measured in the main stream once it leaves the glacier. They are larger by a factor of 2-4 than inferred from tracers injected into moulins in the lower parts of other glaciers (e.g. Stenborg, 1973; Lang and others, 1979), which may in part be a reflection of a time lag between tracer injection in a moulin and its entrance into a principal basal conduit. In any case, the water velocity in this hypothetical conduit would be substantially higher than the length-average velocity of $0.3 \mathrm{~m} \mathrm{~s}^{-1}$ $\left(1 \mathrm{~km} \mathrm{~h}^{-1}\right)$, and the travel time over the $6 \frac{1}{2} \mathrm{~km}$ distance from $\mathrm{km} 10$ to the stream portal would be small compared to the multiple-hour transit time inferred for the turbidity pulse (Table IIIa). Therefore, in this two-zone model most of the time lag occurs in the upper zone.

We now examine the hypothetical distributed flow system above $\mathrm{km} 9$. Table IIIb shows the water velocity inferred from the turbidity delay assuming a transit time from $\mathrm{km} 9$ to the stream portal of $2 \mathrm{~h}$. This roughly accounts for transit through a transition zone and the rapid transit down the conduit below. The inferred water velocities above $\mathrm{km} 9$ are lower than the average over the full length and show a similar proportional scatter but a much reduced absolute spread. Also, a systematic tendency for inferred velocity to be smaller for a more distant origin (Table IIIa) is eliminated (Table IIIb).

If a typical value of about $0.1 \mathrm{~m} \mathrm{~s}^{-1}\left(0.3 \mathrm{~km} \mathrm{~h}^{-1}\right)$ is taken from Table IIIb, Equation (7) gives $A_{\mathrm{T}}$ equal to $123 \mathrm{~m}^{2}, 103 \mathrm{~m}^{2}$, and $48 \mathrm{~m}^{2}$ at $9,6 \frac{1}{2}$, and $4 \mathrm{~km}$, respectively. These are very large areas and imply substantial basal storage of water. The average thickness over the width would be $0.2-0.1 \mathrm{~m}$.

If the water were to flow turbulently in a Röthlisberger conduit, the velocity $0.1 \mathrm{~m} \mathrm{~s}^{-1}$ and Equation (8b) would imply a cross-sectional area $A_{\mathrm{c}}=2.3 \times 10^{-4} \mathrm{~m}^{2}$ $\left(D_{\mathrm{c}}=1.7 \times 10^{-2} \mathrm{~m}\right)$. The corresponding Reynolds number would be 800 , which is too low for turbulence. If the flow is assumed to be laminar, then the circular cross-section would be somewhat smaller, $A_{\mathrm{c}}=1.5 \times 10^{-4} \mathrm{~m}^{2} \quad\left(D_{\mathrm{c}}=1.3 \times\right.$ $10^{-2} \mathrm{~m}$ ) implying a Reynolds number of 600 , which is within the laminar requirement for tubes. Either way, $A_{\mathrm{T}}$ is about $5 \times 10^{5}$ larger than $A_{\mathrm{c}}$, which again indicates the total flow cross-section $A_{\mathrm{T}}$ is much more complex than a single conduit.

It is noteworthy that the water-flow velocity inferred in the basal layer above $\mathrm{km} 9$ (Table IIIb) is close to the propagation velocity of mini-surges (Table IIIc). Also, the Reynolds numbers inferred for the water flow are small $\left(\mathrm{Re}<10^{3}\right)$. These results suggest some questioning of the original assumptions laid out for interpreting turbidity as a water tracer. The turbidity-pulse timing could be alternatively explained, if the water velocity between $\mathrm{km} 9$ and the lower edge of the developing mini-surge were less than the mini-surge propagation speed or the water flow were laminar. In these circumstances, the front edge of the turbid zone would not be carried by the water but by the advancing ice-motion disturbance. Therefore, in this two-zone model, the turbidity might fail as a tracer of physical water velocity in the upper zone.

In spite of these difficulties, it is possible to place an upper limit on the water velocity in the upper zone. If the water velocity is larger than the turbidity propagation speed inferred in Table IIIb, it cannot be so great that the flow would be turbulent. Based on the model of a straight tubelike conduit (Equations (8) and (9)) and a high roughness $\left(n=0.1 \mathrm{~m}^{-1 / 3} \mathrm{~s}\right)$, the transition from laminar to turbulent flow would occur at a velocity of about $0.13 \mathrm{~m} \mathrm{~s}^{-1}$ $\left(0.46 \mathrm{~km} \mathrm{~h}^{-1}\right)$ when $J=0.1$. This is only $30 \%$ larger than the typical turbidity-cloud velocity and is within the range of scatter and possible errors (Table IIIb). In fact, this is likely to be a high estimate for the transition velocity for turbulence since the many passageways implied for this zone are likely to be cross-linked and sinuous which would promote turbulence at lower effective Reynolds numbers and corresponding velocity.

These considerations substantiate a low water velocity in the upper zone that at most could have been slightly larger than the mini-surge propagation speed. They also indicate that the flow may have been laminar, and would not have efficiently transported sediment in suspension out of the mini-surge zone during the intervals between minisurges. It also seems possible that the mobilization of debris by a mini-surge results in part from a transition from laminar to turbulent flow over large bed areas.

Existence of a central conduit running the full glacier length? Is it possible that a central Röthlisberger conduit ran the full length of the glacier during the mini-surges? From the foregoing discussion, the flow in such a conduit would be turbulent and the velocity would be high so that the transit time from the reach affected by mini-surges would be only a few hours. This is much less than the time lag between mini-surge initiation and appearance of the turbidity cloud in the stream. This discrepancy might be explained in two ways: first, if there were delay between mini-surge initiation and injection of turbid water into the local conduit, or secondly, if turbidity is injected at only certain locations which are affected only sometime after mini-surge initiation elsewhere. The first of these possibilities seems unlikely. Comparison of Tables II and II shows the required delay would be $6-24 \mathrm{~h}$ such that the higher the initiation location the longer the delay. The second possibility could be consistent with the pattern of the time lag, if the location of turbidity generation were low in the mini-surge zone. This would be somewhat ad hoc, since there is no reason to expect some special circumstances at any location. Furthermore, this view would prove the existence of a conduit only below the location of turbidity generation, which is then not inconsistent with the two-zone model. Finally, the existence of the mini-surges themselves seems to imply the principal glacier-drainage system has strong hydraulic connection over large areas of the bed. For these reasons, we reject the notion of a straight central conduit on the upper glacier running through the zone of mini-surge propagation during the early melt season when mini-surges occur. One likely possible 
explantion for the cessation of mini-surges later in the melt season could be that by then a central conduit has developed.

\section{DISCUSSION OF THE DIURNAL CYCLE}

The diurnal cycle is caused by the variation in melting rate determined by the surface heat balance. On sunny days this is dominated by the shortwave radiation input (Paterson, 1981) and the melting rate is at a maximum in the early afternoon. On the ice exposed on the lower glacier surface, there is an obvious diurnal variation of water abundance in ponds and streams, and flow into moulins. This variation is probably felt at the bed fairly rapidly but with an uncertain time lag. On the upper glacier, which is covered by firn and snow, there is a small diurnal variation in firn water-table (personal communication from H.F. Engelhardt), but the effects at the bed are likely to be highly dampened and time-lagged because of percolation in the firn and snow. Therefore, the driving of the diurnal variations in the stream is likely to come mostly from the exposed ice on the lower glacier.

The solute load carried by the stream is roughly constant in a typical diurnal cycle. Therefore, to a first approximation, it is reasonable to assume that the solute input rate to the basal system is nearly constant and that the diurnal variation of solute concentration is a result of dilution by a varying discharge. The slight decrease in solute load with increasing discharge indicates that there may be a varying solute input rate negatively correlated with the diurnal discharge. One possible explanation would be a variation in ground-water input to the basal system in response to diurnal basal water-pressure variations.

It is also significant that the diurnal variations of discharge and solute concentration are phased nearly together within the time resolution of about $1-2 \mathrm{~h}$ of the measurements (Fig. 4). This behavior would arise very simply by dilution if the solute were introduced at a constant rate locally at the stream portal. On the other hand, the solute is more likely introduced at a distant location or distributed along the glacier length. In this case, there are two alternative explanations of the phasing. It would be explained, if the physical water and discharge wave speeds were the same. Although this is possible, it would be fortuitous. A second more likely explanation is that both speeds are high, so that the transit times of the discharge wave and water are both short and the difference is necessarily also small.

Finally, we note the discharge peak and solute minimum occur only a few hours after the maximum melt rate. In view of the unknown time lag between surface melting and resulting effects at the bed, it appears that discharge and solute signals must be transferred along the bed to the stream in less than a few hours from large areas of the glacier.

Although these considerations are in no way conclusive, they support the view that there was a well-developed system of large conduits under at least the lower glacier in which water velocities were high and discharge could change rapidly in response to input.

The weak diurnal variation in turbidity may also be consistent with diurnal discharge variation in a system of conduits under the lower glacier. The peak in turbidity on the rising limb of the discharge cycle (Fig. 4) may occur by mobilization of the fine sediments in the conduits by the increasing flow and subsequent exhaustion of the supply. This behavior is typical of open-channel flow (Leopold and others, 1964) and could arise by cyclic deposition and erosion in ponds in a large conduit.

In the long term the interaction of the water and fine debris must be more complex than this. The integrated sediment discharge over the summer corresponds to a settled sediment thickness of $0.02 \mathrm{~m}$ (or $0.01 \mathrm{~m}$ of bedrock accounting for porosity difference) averaged over the area of the glacier bed. This debris must be derived from a large part of the bed; thus conduits migrate across a large percentage of the bed during the summer or water velocity is high enough in the zones of distributed flow to transport the sediment. These and other factors evidently dominate the turbidity and largely mask the diurnal variation.

\section{WATER-STORAGE CHANGES DURING MINI-SURGES}

A water-storage change of $3 \times 10^{5} \mathrm{~m}^{3}$ implied by the anomalous stream discharge after a mini-surge (Fig. 5) corresponds to a layer $0.05 \mathrm{~m}$ thick, if spread evenly, over the approximately $6 \mathrm{~km}^{2}$ area affected by the mini-surges. This is somewhat smaller than the steady-state water crosssection corresponding to a thickness more than $0.1 \mathrm{~m}$, which was inferred earlier to explain the average water flux.

This amount of water-storage change appears to be consistent with changes in ice-surface elevation (uplift) measured by Kamb and Engelhardt (in press), if the uplift is caused by opening and closing of water-filled voids at the bed.

It is also possible that the change in water storage comes from the rise and fall of water in passageways between the surface and bed, that is, changes in internal storage within existing void space without short-term changes in surface elevation (uplift). Large changes in water levels occurred during mini-surges in bore holes reaching the bed (Kamb and Engelhardt, in press). The water-level drop in the later part of a mini-surge was typically about $100 \mathrm{~m}$. If a similar water-level change occurred in connected void space distributed vertically in the glacier, the storage change corresponding to $0.05 \mathrm{~m}$ could be explained if the fractional void volume were only 0.0005 . A connected void-volume fraction larger than 0.0005 seems quite possible and the storage change could be explained by smaller water-level changes in the natural void system than in the bore holes. Also, Balise and Raymond (1985) have shown much of the uplift observed in minisurges may have come from vertical straining of the ice Therefore, it is not certain that all or any of the waterstorage change represents a change in basal storage.

\section{DISCUSSION}

\section{Summary of conclusions}

The conclusions reached above can be summarized as follows. The average velocity of water beneath the glacier from the upper part of the mini-surge zone to the stream is $0.3 \mathrm{~m} \mathrm{~s}^{-1}\left(1 \mathrm{~km} \mathrm{~h}^{-1}\right)$. Together with the water discharge, this indicates that over at least part of the glacier length water flowed in a distributed system of passageways individually much smaller than the total water-flow cross-section. Therefore, a large central conduit running the full length of the glacier was not present. Differences between the lower and upper glacier with regard to their dynamic behavior and the way surface water enters the glacier body, and the diurnal behavior of the stream support the existence of a drainage system beneath the lower glacier dominated by large conduits in which water flows at speeds much greater than $0.3 \mathrm{~m} \mathrm{~s}^{-1}$, perhaps as high as $2.5 \mathrm{~m} \mathrm{~s}^{-1}$. This implies a two-zone model of the basal flow system in which the water velocity is much higher than average in the lower zone and much lower than average in the upper zone.

With these considerations, the water-flow velocity in the upper zone in its unperturbed state below a downglacier propagating mini-surge is deduced to be close to the mini-surge propagation speed $\left(\sim 0.1 \mathrm{~m} \mathrm{~s}^{-1}\right)$ or possibly less. Together with the expected discharge distribution along the glacier length, this implies a total water-flow cross-section of about $10^{2} \mathrm{~m}^{2}$ corresponding to a water thickness averaged over the width of $0.1 \mathrm{~m}$ or more; in contrast, the low water velocity implies individual passageway cross-sections must be smaller by orders of magnitude. The observations place no direct constraint on hydraulic conditions beneath a propagating mini-surge, but the stream discharge indicates a drop in water storage with the termination of a mini-surge that corresponds to a thickness of $0.05 \mathrm{~m}$ averaged over the area affected by mini-surges.

These conclusions apply specifically to the early melt season when mini-surges occurred in a regular cycle. Later in the melt season when mini-surges were less frequent or absent, the basal drainage in the upper zone was evidently different, perhaps because a conduit had formed there. 
Structure of the basal layer in the upper glacier

Based on these constraints on the hydraulics of the upper glacier, it is worthwhile to give additional consideration to the geometry of the distributed passageways that carry the water. Four conceivable views are described here.

The first is a large number of nearly straight, roughly parallel tubes. As calculated above, these would have crosssections $A_{\mathrm{c}}$ of about $2 \times 10^{-4} \mathrm{~m}^{2}$ and diameters $D_{\mathrm{c}}$ about $1-2 \mathrm{~cm}$; it would take roughly $5 \times 10^{5}$ of them to make up the total flow cross-section $A_{\mathrm{T}}$. Over the glacier width of $1 \mathrm{~km}$ there would have to be about $500 / \mathrm{m}$. The combination of diameter and spacing would require that the tubes be distributed vertically, as conduits in the ice or possibly as pipes in unconsolidated basal debris, although the latter of these might not be possible at the low average hydraulic gradient of 0.1 (Baer, 1972). This geometry seems artificial and is probably unrealistic. In any case, the many small passageways are not likely to be realistically modeled by a set of small, straight, non-interconnecting conduits of identical area, roughness, and hydraulic gradient.

A second conceivable structure would be a permeable basal layer of rock debris (Engelhardt and others, 1978). Based on the total water thickness of $0.1-0.2 \mathrm{~m}$ deduced above and a porosity of $0.2-0.3$, this zone would be about $0.3-1 \mathrm{~m}$ thick. In order to produce a physical water velocity of $0.1 \mathrm{~m} \mathrm{~s}^{-1}\left(0.3 \mathrm{~km} \mathrm{~h}^{-1}\right)$ at a hydraulic gradient of 0.1 , the ratio of hydraulic conductivity to porosity would have to be $1 \mathrm{~m} \mathrm{~s}^{-1}$. This is much larger than would be expected for usual granular media. For example, the upper limit of this ratio for clean gravels is $0.1 \mathrm{~m} \mathrm{~s}^{-1}$. Therefore, only in the case that the water velocity is much lower than $0.1 \mathrm{~m} \mathrm{~s}^{-1}$ (say $0.01 \mathrm{~m} \mathrm{~s}^{-1}$ ) would it be possible for the principal water-flow path to be through a granular bed. Then the much larger $A_{\mathrm{T}}$ needed to transport the flux at the lower water velocity would have to be achieved in a much thicker permeable layer (say $2-8 \mathrm{~m}$ ).

A third conceivable structure is a single conduit but with a very high sinuosity, which would produce a very large apparent roughness $n$ in Equation (8b). If it is assumed $A_{\mathrm{c}}=A_{\mathrm{T}}\left(\sim 100 \mathrm{~m}^{2}\right),\langle u\rangle\left(\sim 0.1 \mathrm{~m} \mathrm{~s}^{-1}\right)$ implies an enormous apparent roughness of $n=6.3 \mathrm{~m}^{1 / 3} \mathrm{~s}$ much larger than $0.1 \mathrm{~m}^{1 / 3} \mathrm{~s}$ typical of a Röthlisberger conduit. To explain that would require a sinuosity $y$ of about 10 . This would give conduit cross-section area $\left(\sim 10 \mathrm{~m}^{2}\right)$, effective diameter $(\sim 3.6 \mathrm{~m})$, and velocity $\left(\sim 1 \mathrm{~m} \mathrm{~s}^{-1}\right)$ when measured relative to the local conduit axis. Although this description may not be completely unreasonable, a sinuosity of 10 may be beyond the range where it is useful to think in terms of a single conduit.

A fourth conceivable structure is a network of linked cavities between the ice and the rock (Lliboutry, 1958; Weertman, 1972). The important feature is that the flow passageways are not uniform in cross-section. Then constrictions cause a low velocity and wide places yield a large average thickness. Clearly, the structure of such a system cannot be determined uniquely solely from the mean water thickness and velocity. If one assumes (i) the fractional area of the bed covered by the cavities, (ii) the number of connections between cavities per unit width, (iii) the flow in the connections is given by the Manning's equation (Equation (8a)), and (iv) the hydraulic potential drop occurs entirely in the connections between cavities, then the partitioning of the average thickness and water velocity between the cavities and connections can be calculated rather easily. For example, with a fractional cavity coverage of 0.5 and 1 connection per meter width, the mean thickness $0.1 \mathrm{~m}$, and velocity $0.1 \mathrm{~m} \mathrm{~s}^{-1}$ imply a mean thickness and velocity of $0.18 \mathrm{~m}$ and $0.05 \mathrm{~m} \mathrm{~s}^{-1}$ in the cavities, and $0.02 \mathrm{~m}$ and $0.6 \mathrm{~m} \mathrm{~s}^{-1}$ in the connections. Although the numerical values assumed are arbitrary, the example shows that a quite reasonable structure of linked cavities can explain the combination of low water velocity and large flow cross-section area inferred for the upper glacier.

Based on the stream behavior alone, any of these views of the basal hydraulic system above $\mathrm{km} 9$ seem possible at the present level of analysis. Also, we can imagine these structures may exist in combinations. However, each of these structures raises questions concerning stability in the presence of sliding motion, shearing in the basal ice or in a sub-sole permeable drift, erosion of the bed, or sediment- ation in the passageways. These considerations will be essential to further theoretical constraining of the structure of the distributed basal system.

\section{ACKNOWLEDGEMENTS}

This work was carried out with funding from the National Science Foundation, Division of Polar Programs (grant numbers DPP-7903942 and 8200725). We would especially like to express our thanks to T. Pfeffer, L. Senear, and the late G. Anderson, who helped with field work, and T. Lee, who helped with design and construction of field electronics.

\section{REFERENCES}

Baer, J. 1972. Dynamics of fluids in porous media. New York, American Elsevier Publishing Company.

Balise, M.J., and Raymond, C.F. 1985. Transfer of basal sliding variations to the surface of a linearly viscous glacier. Journal of Glaciology, Vol. 31, No. 109, p. 308-18.

Bindschadler, R., and others. 1976. Thermal regime of a surge-type glacier, by R. Bindschadler, W.D. Harrison, C.F. Raymond, and C. Gantet. Journal of Glaciology, Vol. 16, No. 74, p. 251-59.

Bindschadler, R., and others. 1977. Geometry and dynamics of a surge-type glacier, by R. Bindschadler, W.D. Harrison, C.F. Raymond, and R. Crosson. Journal of Glaciology, Vol. 18, No. 79, p. 181-94.

Clarke, G.K.C. 1982. Glacier outburst floods from "Hazard Lake", Yukon Territory, and the problem of flood magnitude prediction. Journal of Glaciology, Vol. 28, No. 98 , p. 3-21.

Collins, D.N. 1978. Hydrology of an Alpine glacier as indicated by the chemical composition of meltwater Zeitschrift für Gletscherkunde und Glazialgeologie, Bd. 13, 1977 , p. 219-38.

Collins, D.N. 1979. Sediment concentration in melt waters as an indicator of erosion processes beneath an Alpine glacier. Journal of Glaciology, Vol. 23, No. 89, p. 247-57.

Collins, D.N. 1981. Seasonal variation of solute concentration in melt waters draining from an Alpine glacier. Annals of Glaciology, Vol. 2, p. 11-16.

Engelhardt, H.F., and others. 1978. Basal sliding and conditions at the glacier bed as revealed by bore-hole photography, by H.F. Engelhardt, W.D. Harrison, and B. Kamb. Journal of Glaciology, Vol. 20, No. 84, p. 469-508.

Greenberg, A.E., and others, eds. 1981. Standard methods for the examination of water and wastewater. 15th edition. Edited by A.E. Greenberg, J.J. Connors, and D. Jenkins. New York, American Public Health Association.

Harrison, W.D., and others. 1986. Short period motion events on Variegated Glacier as observed by automatic photography and seismic methods, by W.D. Harrison, C.F. Raymond, and P. MacKeith. Annals of Glaciology, Vol. 8, p. $82-89$

Hodge, S.M. 1974. Variations in the sliding of a temperate glacier. Journal of Glaciology, Vol. 13, No. 69, p. 349-69.

Iken, A. 1978. Variations of surface velocities of some Alpine glaciers measured at intervals of a few hours. Comparison with Arctic glaciers. Zeitschrift für Gletscherkunde und Glazialgeologie, Bd. 13, 1977, p. 23-35.

Kamb, B., and Engelhardt, H.F. In press. Waves of accelerated motion in a glacier approaching surge: the mini-surges of Variegated Glacier, Alaska, U.S.A. Journal of Glaciology.

Leopold, L.B., and others. 1964. Fluvial processes in geomorphology, by L.B. Leopold, M.G. Wolman, and J.P. Miller. San Francisco, W.H. Freeman \& Co.

Lang, H., and others. 1979. Results from tracer experiments on the water flow through the Aletschgletscher, by $\mathrm{H}$ Lang, C. Leibundgut, and E. Festel. Zeitschrift für Gletscherkunde und Glazialgeologie, Bd. 15, Ht. 2, p. 209-18. 
Lliboutry, L. 1968. General theory of subglacial cavitation and sliding of temperate glaciers. Journal of Glaciology, Vol. 7, No. 49, p. 21-58.

Meier, M.F. 1969. Glaciers and water supply. Journal of the American Water Works Association, Vol. 61, No. 1, p. 8-12.

Nye, J.F. 1976. Water flow in glaciers: jökulhlaups, tunnels and veins. Journal of Glaciology, Vol. 17, No. 76, p. 181-207.

Østrem, G. 1975. Sediment transport in glacial meltwater streams. (In Jopling, A.V., and McDonald, B.C., eds. Glaciofluvial and glaciolacustrine sedimentation. Tulsa, OK, Society of Economic Paleontologists and Mineralogists, p. 101-22. (Special Publication No. 23.))

Paterson, W.S.B. 1964. Variations in velocity of Athabasca Glacier with time. Journal of Glaciology, Vol. 5, No. 39, p. 277-85.

Paterson, W.S.B. 1981. The physics of glaciers. Second edition. Oxford, etc., Pergamon Press. (Pergamon International Library.)

Raymond, C.F., and Malone, S.D. 1986. Propagating strain anomalies on Variegated Glacier, Alaska, U.S.A. Journal of Glaciology, Vol. 32, No. 111, p. 195-207.
Röthlisberger, H. 1972. Water pressure in intra- and subglacial channels. Journal of Glaciology, Vol. 11, No. 62 , p. $177-203$.

Shreve, R.L. 1972. Movement of water in glaciers. Journal of Glaciology, Vol. 11, No. 62, p. 205-14.

Stenborg, T. 1973. Some viewpoints on the internal drainage of glaciers. Union Géodésique et Géophysique Internationale. Association Internationale d'Hydrologie Scientifique. Commission de Neiges et Glaces. Symposium on the Hydrology of Glaciers, Cambridge, 7-13 September 1969 , p. 117-29. (Publication No. 95 de l'Association Internationale d'Hydrologie Scientifique.)

Tangborn, W.V., and others. 1975. A comparison of glacier mass balance by glaciological, hydrological, and mapping methods, South Cascade Glacier, Washington, by W.F. Tangborn, R.M. Krimmel, and M.F. Meier. [Union Géodésique et Géophysique Internationale. Association Internationale des Sciences Hydrologiques. Commission des Neiges et Glaces.] Symposium. Neiges et glaces. Actes du colloque de Moscou, août 1971, p. 185-96. (IAHS-AISH Publication No. 104.)

Weertman, J. 1972. General theory of water flow at the base of a glacier or ice sheet. Reviews of Geophysics and Space Physics, Vol. 10, No. 1, p. 287-333. 